$\mathbf{Y}$

eats, William Butler (1865-1939) Irish poet and dramatist; see *ceremony, *myth.

\section{Young Hegelians}

Philosophers, theologians, and political theorists in the 1830s and 1840s, with whom both Marx and Engels came into contact, and who attempted to adapt and transform Hegel's philosophy so as to give it a coherent critical and practical application. They included the theologians David Strauss (1808-74) and Bruno Bauer (1809-82), who were strongly influenced by Hegel's theory of universal history, the reactionary individualist *Stirner, a brilliant polemicist who foreshadowed Nietzsche's philosophy of self-enhancement, and the critic and philosopher Ludwig Feuerbach (1804-72), whose sophisticated iconoclasm had a profound effect on the younger generation of intellectuals. Feuerbach was interested in giving a *materialist version of the Hegelian philosophy of the self. He argued that man's essence is social, and resides in the *species-being that he shares with his kind. Only man has species-being, since only man has to find his own nature, by interacting with his kind. The alienated character of religion, as Hegel had described it, comes about because men carry that search beyond their social existence, into a transcendental realm which they do not understand. They then project out of themselves, and make into properties of the divinity, the perfections that might have been theirs. These perfections can have no reality outside man's social life, but there they have real existence. In removing his perfection from himself and bestowing it on a transcendent being, man makes his own perfection unobtainable, since it now lies outside the sphere of social action. This is the *fetishism which constitutes the essence of religious belief, and also the true divorce between man and his species-being (The Essence of Christianity, 1841).

All the Young Hegelians shared this interest in, and to some extent reaction against, religion, and all of them endeavoured to detach the Hegelian philosophy from its uncompromising metaphysical idealism. Feuerbach's theories recur in the early theories of Marx, particularly that concerning *alienation and were profoundly influential on Richard Wagner, and on the idea of myth and its significance that inspired The Ring of the Nibelung.

\section{yuppie}

'Young upwardly mobile professional'. The 'new class' emerging from the service economy of the modern capitalist state, which has brought about radical and to some extent unforeseen changes in lifestyle and voting habits, especially among urban electorates. 